\section{Influence of Different Types of Resin Luting Agents on Color Stability of Ceramic Laminate Veneers Subjected to Accelerated Artificial Aging}

Francisca Daniele Jardilino Silami, Rafaella Tonani, Carla Cecilia Alandia-

Román, Fernanda de Carvalho Panzeri Pires-de-Souza
Department of Dental Materials and Prosthodontics. Dental School of Ribeirão Preto, USP - Universidade de São Paulo, Ribeirão Preto, SP, Brazil

Correspondence: Profa. Dra. Fernanda de Carvalho Panzeri Pires-de-Souza, Avenida do Café s/n, 14040-904 Ribeirão Preto, SP, Brasil. Tel.: +55-163602-3973. e-mail: ferpanzeri@usp.br
The aim of this study was to evaluate the influence of accelerated aging (AAA) on the color stability of resin cements for bonding ceramic laminate veneers of different thicknesses. The occlusal surfaces of 80 healthy human molars were flattened. Ceramic laminate veneers (IPS e-max Ceram) of two thicknesses $(0.5$ and $1.0 \mathrm{~mm})$ were bonded with three types of luting agents: light-cured, conventional dual and self-adhesive dual cement. Teeth without restorations and cement samples $(0.5 \mathrm{~mm})$ were used as control. After initial color evaluations, the samples were subjected to AAA for $580 \mathrm{~h}$. After this, new color readouts were made, and the color stability $(\Delta \mathrm{E})$ and luminosity $(\Delta \mathrm{L})$ data were analyzed. The greatest color changes $(p<0.05)$ occurred when $0.5 \mathrm{~mm}$ veneers were fixed with lightcured cement and the lowest when $1.0 \mathrm{~mm}$ veneers were fixed with conventional dual cement. There was no influence of the restoration thickness when the self-adhesive dual cement was used. When veneers were compared with the control groups, it was verified that the cement samples presented the greatest alterations $(p<0.05)$ in comparison with both substrates and restored teeth. Therefore, it was concluded that the thickness of the restoration influences color and luminosity changes for conventional dual and light-cured cements. The changes in self-adhesive cement do not depend on restoration thickness.
Key Words: resin cements, dental veneers, thickness, aging, color stability.

\section{Introduction}

Laminate veneers are indirect restorations performed by conservative techniques with the purpose of harmonizing the smile, restoring the adequate color, shape and function of esthetically compromised teeth (1). Dental ceramic is the material of choice for this type of restoration, as it presents excellent properties, among which color stability (2), chemical inertia (3), translucence $(4,5)$ and high capacity to mimic tooth structure (1), as it is the restorative material that most closely resembles the optical properties of teeth (5).

However, the success of clinical treatment depends on the perfect combination of colors between the restoration and remaining teeth, and there are many variables involved, like the color of the supporting tooth substructure (6), thickness, shade and type of ceramic (2) and resin cement (7), in addition to the restorative material's translucency shown by the amount of reflection and scattering of light (5).

The longevity of the restoration is related to the material's color stability $(8,9)$ and partly depends on the used cementation technique $(10,11)$. Resin cements are indicated for bonding these restorations due to the low amount of retention of conservative preparations (9). Various types of resin cements are indicated for cementation of ceramic laminate veneers $(2,9)$ and many professionals prefer the light-cured cements, due to the possibility of controlling the cement activation by light, which allows optimization of the technique and longer clinical working time (10). Self-adhesive cements appeared on the market with the proposal of simplifying the adhesive bonding technique, with application of cement in a single step, eliminating the prior treatment of dental substrate and diminishing the technique sensitivity. These cements have bond strengths comparable with the ones of conventional resin cements (11). The activation system of resin cements may have an influence on the color stability of thin restorations and the influence of self-adhesive cements on the color stability of ceramic laminate veneers must be more clarified.

For in vitro studies, Accelerated Artificial Aging (AAA) has been shown to be an efficient method for evaluating the longevity of different dental materials. This technique simulates the clinical parameters $(9,12)$ as far as possible, due to the action of different conditions to which the material is subjected, such as UV light, continuous alterations in temperature and humidity, and it has been used to evaluate the color stability of dental restorations, including resin cements and all-ceramic restorations (13). However, the effects of aging on the cement subjacent 
to the porcelain restoration are unknown, particularly as regards the thinner types, which are more translucent, since there is less material between restoration and substrate.

Thus, the aim of the present study was to evaluate the effect of AAA on the color change of three types of resin cements under ceramic laminate veneers of different thicknesses. The work hypothesis tested was that there would be no difference in color stability of the restorations related to the cements and that the cements used with thinner restorations would present greater color change.

\section{Methods and Materials}

After approval from the institutional Ethics Committee, 130 human molars were selected from the FORP/USP tooth bank. Fifty teeth with white spot lesions, signs of demineralization, fractures, abrasions and gaps were excluded, and then 80 teeth were used in this study.

After prophylaxis with pumice stone and rubber cup for $30 \mathrm{~s}$, all teeth were embedded in chemically activated acrylic resin (Vipi Flash; Vipi, Pirassununga, SP, Brazil) up to the cementoenamel junction. The occlusal surfaces were flattened with abrasive papers (Agua Advance; Norton, São Paulo, SP, Brazil) of decreasing granulations $(100,320,600$, 800 and 1000), until a flat surface was obtained. Forty teeth were abraded up to the level of dentin and the other 40 up to the enamel (by lowering the cusps and with care not to cause exposure of dentin).

The $8 \mathrm{~mm}$ diameter laminate veneers (IPS e-Max Ceram; Ivoclar Vivadent, Schaan, Liechtenstein) of two thicknesses $(0.5$ and $1.0 \mathrm{~mm}$ ) were obtained in incisal color, using a Teflon matrix. The samples were sintered (AluminiSinter Press EDG, São Carlos, SP, Brazil) on lining bases (Duravest, Polidental, São Carlos, SP, Brazil), according to the manufacturer's recommendations. The specimens were polished (Polipan-U, Panambra São Paulo, SP, Brazil) with abrasive papers in decreasing order of abrasiveness (600, 1000 and 1200), and their thickness was checked with a digital caliper (Digimess Precision, São Paulo, SP, Brazil). Glazing was performed at $403{ }^{\circ} \mathrm{C}$ for 4 min and $700{ }^{\circ} \mathrm{C}$ for $1 \mathrm{~min}$, according to the manufacturer's instructions.

The specimens of each thickness were randomly divided into 3 groups $(n=10)$, according to the used type of cement (Table 1). Treatment of the intaglio surface consisted of etching with 10\% hydrofluoric acid (Dentsply, Petrópolis, RJ, Brazil) for $20 \mathrm{~s}$, cleaning by water and air spray, silane application (Monobond S; Ivoclar/Vivadent) for $1 \mathrm{~min}$ and drying with hot air. Treatment of the substrates is described in Table 1. The self-adhesive cement eliminates the need for any previous treatment before cementation.

Before cementation with conventional dual and lightcured (Variolink II; Ivoclar/Vivadent, Schaan, Liechtenstein) cements, adhesive (Tetric N Bond; Ivoclar/Vivadent) was applied on the part that was light activated (FLASHlite 1401; Discus Dental, Liechtenstein; 460-480 nm wavelength, $1.100 \mathrm{~mW} / \mathrm{cm}^{2}$ ) for $20 \mathrm{~s}$.

The cement was applied to the occlusal surface of the tooth, and the specimen seated with the help of a delineator rod to guarantee parallelism during fixation of the veneer, on which a load of $380 \mathrm{~g}$ was placed to standardize cement thickness before light activation. After removing the weight, the LED activator light was applied for $3 \mathrm{~s}$, and the excess cement removed with an exploratory probe. After this, light activation was performed as manufacturer's recommendation for $40 \mathrm{~s}$.

Two control groups were obtained: one related to the cements and the other to the tooth substrate. Thus, 30 specimens of the cements $(n=10)$ were fabricated, using the same Teflon matrix in a single thickness $(0.5 \mathrm{~mm})$ and 20 teeth $(n=10)$ were abraded in enamel and in dentin, on which no test specimen or cement was fixed.

After this, the initial color readouts (Vita Easyshade; VITA Zahnfabrik, Bad Säckingen, Germany) were taken for all the samples. This portable appliance has a $6 \mathrm{~mm}$ diameter digital pointer, 19 individual fiber optics that illuminate the restorative material and 2 spectrophometric sensors able to read color numerically. The observation pattern simulated by the Spectrophotometric colorimeter followed the CIE L*a* ${ }^{*}{ }^{*}$ system (14), recommended by CIE (Comission Internationale de L'Éclairage), used in the study $(15,16)$. For color readout, the pointer was centralized and placed on the test specimen that occupied its entire diameter, allowing readout in the same position at all times. The optical geometry of color measurement of this appliance is circular with the specular component excluded, which simulates a 45/0 measurement. The standard illuminant is $D_{65}$ and a standard observer of 20 . The excluded specular

Table 1. Studied groups

\begin{tabular}{|c|c|c|c|}
\hline Group & Cement & Substrate & Substrate treatment \\
\hline G1 & Rely-X Unicem & Dentin & - \\
\hline G2 & $\begin{array}{c}\text { Variolink II } \\
\text { (light-cured base paste) }\end{array}$ & Enamel & $\begin{array}{l}\text { Etching with } 37 \% \text { phosphoric acid (Condac } 37 \text {; FGM) for } 30 \\
\text { s; washing; excess moisture removal with absorbent paper; }\end{array}$ \\
\hline G3 & $\begin{array}{l}\text { Variolink II } \\
\text { (base and catalyst pastes) }\end{array}$ & Enamel & $\begin{array}{l}\text { application of adhesive system (Tetric N Bond; Ivoclar/ } \\
\text { Vivadent) and light activation (FLASHlite 1401) for } 20 \text { s }\end{array}$ \\
\hline
\end{tabular}


component is related to the color measurement on the sample surface to prevent the interference of surface brightness $(15,16)$.

After the initial readouts, the samples were submitted to Accelerated Artificial Aging (AAA, Accelerated Aging System for non-metals C-UV; Comexim, São Paulo, SP, Brazil) for $580 \mathrm{~h}$ (17). This system simulates the forces of nature, predicting the relative durability of materials exposed to the weather, which are simulated by a network of eight sources of ultraviolet light (UV-B). It has $40 \mathrm{~W}$ fluorescent tubes with emission concentrated in the ultraviolet $B$ region and radiation concentrated at $280 / 320 \mathrm{~nm}$, as it occurs in nature. The exposure temperature was automatically controlled according to the programs established for the $\mathrm{UV} /$ condensation cycles. The used working program was fixed at $4 \mathrm{~h}$ of exposure to UV-B at $50^{\circ} \mathrm{C}$ and $4 \mathrm{~h}$ of vapor condensation at $50{ }^{\circ} \mathrm{C}$.

After this, new color readouts were taken and the color change $(\Delta \mathrm{E})$ calculated by means of the following formula (2): $\Delta \mathrm{E}=\left[(\Delta \mathrm{L})^{2}+(\Delta \mathrm{a})^{2}+(\Delta \mathrm{b})^{2}\right]^{1 / 2}$; where $\Delta \mathrm{E}=$ color change; $\Delta \mathrm{L}=$ lightness difference $\left(\mathrm{L}^{*}\right)$, so that the greater $L^{*}$ values, the higher the brightness of the sample; $\Delta a=$ axis $\mathrm{a}^{*}$ difference; so that positive values for $\Delta \mathrm{a}$ means redder samples and negative values, greener; $\Delta \mathrm{b}=\mathrm{axis} \mathrm{b}^{*}$ difference; so that positive values for $\Delta \mathrm{b}$ mean yellower samples and negative values bluer, where: $\Delta \mathrm{L}=\mathrm{L}^{*}-\mathrm{L}^{*}{ }_{1 ;} \Delta \mathrm{a}=\mathrm{a}^{*}{ }_{\mathrm{F}}-\mathrm{a}^{*}{ }_{1 ;}$

Table 2. Comparison of the means of $\Delta \mathrm{E}$ and $\Delta \mathrm{L}$ (2-way ANOVA, Bonferroni, $\mathrm{p}<0.05$ )

\begin{tabular}{cccc}
\hline & $\begin{array}{c}\text { Conventional } \\
\text { Dual }\end{array}$ & $\begin{array}{c}\text { Self-adhesive } \\
\text { Dual }\end{array}$ & Light-cured \\
\hline$\Delta \mathrm{E}$ & & & \\
$0.5 \mathrm{~mm}$ & $9.39 \pm 2.89 \mathrm{Aa}$ & $8.28 \pm 2.43 \mathrm{Aa}$ & $14.29 \pm 1.78 \mathrm{Ab}$ \\
$1.0 \mathrm{~mm}$ & $5.27 \pm 2.94 \mathrm{Ba}$ & $7.75 \pm 2.90 \mathrm{Aa}$ & $10.05 \pm 1.38 \mathrm{Bb}$ \\
$\Delta \mathrm{L}$ & & & \\
$0.5 \mathrm{~mm}$ & $8.37 \pm 3.0 \mathrm{Aa}$ & $6.37 \pm 2.86 \mathrm{Aa}$ & $12.39 \pm 1.23 \mathrm{Ab}$ \\
$1.0 \mathrm{~mm}$ & $4.15 \pm 3.21 \mathrm{Ba}$ & $5.35 \pm 5.49 \mathrm{Aa}$ & $8.27 \pm 1.28 \mathrm{Bb}$ \\
\hline
\end{tabular}

Different letters, capitals in the column, and lowercase letters in the row indicate statistically significant results $(\mathrm{p}<0.05)$.

Table 3. Comparison of $\Delta \mathrm{E}$ means of ceramic laminate veneers of two thicknesses bonded with different cements and with control groups (cement and substrate)

\begin{tabular}{lccc}
\hline & $\begin{array}{c}\text { Conventional } \\
\text { Dual }\end{array}$ & $\begin{array}{c}\text { Self-adhesive } \\
\text { Dual }\end{array}$ & Light-cured \\
\hline $0.5 \mathrm{~mm}$ & $9.39 \pm 2.89 \mathrm{~A}$ & $8.27 \pm 2.43 \mathrm{~A}$ & $14.29 \pm 1.23 \mathrm{~A}$ \\
$1.0 \mathrm{~mm}$ & $5.27 \pm 2.94 \mathrm{~B}$ & $7.74 \pm 2.91 \mathrm{~A}$ & $10.05 \pm 1.28 \mathrm{~B}$ \\
Substrate & $12.47 \pm 3.92 \mathrm{~A}$ & $16.82 \pm 7.44 \mathrm{~B}$ & $12.47 \pm 3.92 \mathrm{AB}$ \\
Cement & $25.68 \pm 1.52 \mathrm{C}$ & $38.97 \pm 1.25 \mathrm{C}$ & $28.65 \pm 2.77 \mathrm{C}$ \\
\hline
\end{tabular}

Different letters in the column indicate statistically significant difference $(p<0.05)$ between the samples.
$\Delta \mathrm{b}=\mathrm{b}^{*}{ }_{\mathrm{F}}-\mathrm{b}^{*}{ }_{1}$, where $\mathrm{L}^{*}{ }_{1}, \mathrm{a}^{*}{ }_{1} \mathrm{e} \mathrm{b}^{*}$ are referred to as the initial color measurement and $\mathrm{L}^{*}{ }_{\mathrm{F}} \mathrm{a}_{\mathrm{F}}^{*}$ and $\mathrm{b}^{*} \mathrm{~F}$ as the final color measurement.

The values of $\Delta \mathrm{E}$ and $\Delta \mathrm{L}$ were compared according to the used type of cement and different thicknesses of the laminate veneers, using 2-way ANOVA, Bonferroni $(p<0.05)$. In addition, the measurements of $\Delta \mathrm{E}$ and $\Delta \mathrm{L}$ for each cement, in the studied two thicknesses, were compared (one way ANOVA, Tukey, $p<0.05$ ) with the values of the control groups (cement and tooth with substrate relative to the cement used).

\section{Results}

Comparison of the mean values of $\Delta \mathrm{E}$ and $\Delta \mathrm{L}$ (2-way ANOVA, Bonferroni test, $\mathrm{p}<0.05)$, are presented in Table 2 .

It was verified that restorations fixed with the lightcured cement presented greater color and luminosity alteration $(p<0.05)$, irrespective of the restoration thickness, in comparison with the other cements, which presented no difference among them ( $p>0.05)$.

When the materials were analyzed considering the restoration thicknesses, thin restorations presented greater change in color and luminosity $(p<0.05)$ when cemented with the light-cured cement, followed by the conventional dual cement. There was no statistically significant difference ( $p>0.05$ ) for the self-adhesive dual cement. Analysis of $\Delta L$ demonstrated reduction in luminosity for all three materials.

Color change $(\Delta \mathrm{E})$ and luminosity $(\Delta \mathrm{L})$ were also compared (one-way ANOVA, Tukey, $p<0.05$ ) with the cementing agent and the control groups (tooth and cement) and the mean values are presented in Tables 3 and 4 , respectively.

The greatest color change occurred for all cements with difference $(p<0.05)$ from substrates and restored teeth. The substrates also presented high levels of color alteration. Enamel had the same level of change as that of $0.5 \mathrm{~mm}$ restorations ( $p>0.05$ ) for conventional dual and light-cured cements and dentin. When dual self-adhesive cement was used, it presented greater alterations $(p<0.05)$ when compared with the restorations and cement.

Table 4. Comparison of $\Delta \mathrm{L}$ means of ceramic laminate veneers of two tested thicknesses, bonded with different cements and with control groups (cement and substrate)

\begin{tabular}{llll}
\hline & $\begin{array}{c}\text { Conventional } \\
\text { Dual }\end{array}$ & \multicolumn{1}{c}{$\begin{array}{c}\text { Self-adhesive } \\
\text { Dual }\end{array}$} & \multicolumn{1}{c}{ Light-cured } \\
\hline $0.5 \mathrm{~mm}$ & $8.37 \pm 3.00 \mathrm{~A}$ & $6.37 \pm 2.86 \mathrm{~A}$ & $12.39 \pm 1.23 \mathrm{~A}$ \\
$1.0 \mathrm{~mm}$ & $4.15 \pm 3.21 \mathrm{~B}$ & $5.35 \pm 5.49 \mathrm{~A}$ & $8.151 .28 \mathrm{~B}$ \\
Substrate & $-7.21 \pm 4.08 \mathrm{C}$ & $-6.39 \pm 14.21 \mathrm{~B}$ & $-7.21 \pm 4.08 \mathrm{C}$ \\
Cement & $-14.63 \pm 2.68 \mathrm{D}$ & $-25.78 \pm 3.70 \mathrm{C}$ & $-5.21 \pm 2.77 \mathrm{C}$ \\
\hline
\end{tabular}

Different letters in the column indicate statistically significant difference $(\mathrm{p}<0.05)$ between the samples. 
There was an increase in luminosity in the groups with restorations and reduction in the control groups, for all cements. The greatest loss of luminosity occurred in the cement, followed by the substrate, different $(p<0.05)$ between them, except for the light-cured cement, which showed no difference $(p>0.05)$ between cement and substrate.

\section{Discussion}

The study hypothesis was that the cements used for bonding thinner restorations would present greater color change and that there would be no difference in color stability of the restorations considering the cementing agent. The results of the study indicate that the hypothesis was not accepted, because the restoration thickness was a significant factor for color stability of the conventional dual and light-cured cements, and there was greater change in color of the light-cured cement.

The type of substructure of a translucent restoration may influence the color readout. In the present study, color readouts were taken before and after aging, so the substrate would not interfere in the final color results. Therefore, dental substrate was used for the resin cement and a clinical situation was simulated. It was possible to determine which component (tooth or cement) may have more influence on the final color change of the restorations and also if the thickness of the restoration would be able to neutralize/mask the occurred color change. In this study, samples 0.5 and $1.0 \mathrm{~mm}$ thick were used; it is known that a standard laminate thickness is $0.7 \mathrm{~mm}$ (1). However, in a clinical situation, it is not always possible to get laminates of that exact measure, so we considered important to foresee what would happen with greater or lesser thicknesses. The incisal color was selected for the study because it is the most translucent color, so the changes that could occur would be greater than in more opaque colors.

When the conventional dual and light-cured cements were used, the dental substrate for cementation was enamel, and when the self-adhesive cement was used, the dental substrate was dentin, due to a better indication of Rely-X Unicem cement (11).

As the color stability of the resin cement was analyzed in a ceramic restoration on a tooth, it would be difficult to determine whether the resulting alteration resulted from alteration of the cement or the tooth. Therefore, the experimental design of the study included two control groups, one with resin cement only and the other only with the involved dental substrates. Due to the limitations of this in vitro study, in the case of the control group with resin cements, the thickness used for obtaining the sample $(0.5 \mathrm{~mm})$ is much larger than the clinical film thickness of the cement, because color analysis and AAA tests demand a minimum thickness for obtaining reliable results (13).

As regards the color stability of cements, all of them presented color change above 3.3, considered clinically unacceptable, $(2,18)$ with statistically significant difference $(p<0.05)$ for the light-cured cement. This may have been caused by the high concentration of photosensitive materials in the composition of this cement (12), like aliphatic and aromatic tertiary amines (19). The UV light, temperature and humidity of the AAA equipment may cause oxidation of amine and degradation of camphorquinone (18) used in the polymerization process of the cements, resulting in yellowing of the material over the course of time (20).

Allied to these factors, the degradation of residual amines and oxidation of the unreacted double carbon bonds may form more yellowed compounds (8) and the stain resistance depends on the properties of monomers (21). All the used cements presented TEGDMA in their composition, which contributes to color change of the material, because TEGDMA-based materials release larger quantities of monomers in an aqueous environment, when compared with other methacrylate monomers (22) and when associated with Bis-GMA-based materials, the water sorption of the composite is directly proportional to the concentration of TEGDMA in the composition (9). This would justify the high $\Delta E$ values found in all cements.

The conventional dual and light-cured cements presented greater color change when used for bonding thinner veneers, with statistically significant difference $(p<0.05)$ in comparison with the $1.0 \mathrm{~mm}$ thick veneer, results similar to those of Kucukesmen et al. (23). The opacity of ceramic varies and may serve to mask the color change of the cement under it, which is dependent on the thickness of the material and $0.5 \mathrm{~mm}$ thick porcelain is unable produce this effect (2). However, another study (7) has suggested that thickness of at least $2.0 \mathrm{~mm}$ would be able of mitigating the effects of the adjacent substrate on the final color of the restoration.

Restorations cemented with self-adhesive dual cement did not present the same results, because for both ceramic thicknesses the color change was similar ( $p>0.05$ ). This cement has bi-functional methacrylate groups (phosphorylated methacrylate) in its composition, which interfere in the conversion degree of the cement. This occurs because in addition to the light and chemical activation reaction, both via free radicals, there is an acid/ base reaction. In this reaction, the functional groups of modified phosphoric acid, negatively charged due to the acid, react with the calcium ions of the tooth and with the alkaline part of the filler particles, in a neutralization reaction (11).

The $L^{*}$ coordinate indicates the amount of black and 
white a color has and varies from 0 (black) to 100 (white). When the teeth were restored, the $\Delta \mathrm{L}$ was found to have positive values, indicating an increase in luminosity, whereas the control groups (tooth and cement) presented negative values, with reduction in luminosity (23). Therefore, one understands that the presence of the ceramic laminate veneers was a determinant fact for the change in luminosity and consequently the color of the material. This may occur due to increase in the absorption of incident light when the material is without the restoration, which results in a reduced quantity of reflected light, and thus a lower value of $L^{*}(24)$. Similar results were found with higher $L^{*}$ values for ceramic in comparison with human dentin (4). This would justify the higher values of $\Delta L$ after AAA, in comparison with the teeth and cement.

These changes in $\Delta \mathrm{E}$ and $\Delta \mathrm{L}$ of the cements with restorations may be justified by the attenuating capacity the ceramic laminate veneers may have on the passage of UV light of AAA (21) and by the ceramic masking the color change of the cement (9).

The enamel and dentin control groups presented high standard deviation values, for both color stability $(\Delta \mathrm{E})$ and luminosity $(\Delta \mathrm{L})$, with the highest values occurring in dentin. Studies have proven that when the luminosity $\left(L^{*}\right)$ of the natural tooth is low, there is high discrepancy between the color coordinates measured by the equipment for this purpose (25). Therefore, the high standard deviation values may be justified by the color variation in the dental substrate. There is no rigid color standard for these structures and this change is greater for dentin because it has more opacity and saturation than enamel.

One limitation is that this study used a single vitreous ceramic shade, a single resin cement color and a unique method of aging. Artificial accelerated aging does not reproduce accurately a clinical condition because of its drastic effects over dental materials subjected to the process of aging. However, as clinical studies assessing the long-term behavior of dental materials are extremely difficult, laboratory aging methods have been proposed to standardize the research. $(18,19)$ Thus, despite these effects being greater than the ones that would occur in an oral cavity, this method aims to accelerate the degradation of materials in order to meet a time effective answer whether the tested materials are resistant to degradation in vitro over time.

Further studies are required to evaluate the color change of the dental ceramic/resin cement set when subjected to other aging methods, variations in technique for obtaining restorations and other physical characteristics of the involved materials.

Considering these limitations, it was possible to conclude that the overall color alteration of ceramic laminate veneers submitted to AAA is directly related to color change in resin cements, which seems to be related to changes in luminosity. The thinner the restoration thickness $(0.5 \mathrm{~mm})$, the greater the changes when conventional dual and light-cured cements are used. On the other hand, when self-adhesive cement is used, the alterations do not depend on the restoration thickness. The ceramic laminate veneer protects the resin cement and substrate from the influence of AAA, although it may also act as attenuating factor on the color change occurring subjacent to it.

\section{Resumo}

0 objetivo deste estudo foi avaliar a influência do envelhecimento artificial acelerado (EAA) sobre a estabilidade de cor de cimentos resinosos para fixação de laminados cerâmicos em diferentes espessuras. Oitenta molares humanos hígidos tiveram as faces oclusais planificadas. Laminados cerâmicos (IPS e-max Ceram, Ivoclar Vivadent) em duas espessuras (0,5 e 1,0mm) foram fixados com 3 tipos de cimentos: Fotoativado (Variolink II, Ivoclar/Vivadent), Dual convencional (Variolink II + catalisador, Ivoclar/ Vivadent) ou Dual auto-adesivo (Rely-X Unicem, 3M ESPE). Dentes sem restaurações e amostras de cimentos $(0,5 \mathrm{~mm})$ foram utilizados como controle. Após as leituras de cor iniciais (Vita EasyShade, VITA), as amostras foram submetidas a EAA por 580 horas. Em seguida, novas leituras de cor foram realizadas e os dados de estabilidade de cor $(\triangle E)$ e luminosidade $(\Delta \mathrm{L})$ foram analisados (ANOVA, dois fatores e Bonferroni, $\mathrm{p}<0,05$ ). As maiores alterações de cor $(p<0,05)$ ocorreram quando as restaurações de $0,5 \mathrm{~mm}$ foram fixadas com cimento fotoativado, e as menores quando restaurações de $1.0 \mathrm{~mm}$ foram fixadas com cimento dual convencional. Não houve influência $(p>0,05)$ da espessura da restauração quando utilizado o cimento dual autoadesivo. Quando as restaurações foram comparadas aos grupos controle (ANOVA um fator e Tukey, $p<0.05$ ), verificou-se que as amostras de cimento apresentaram as maiores alterações $(p<0,05)$ em relação ao substrato e aos dentes restaurados. Conclui-se que a espessura da restauração influencia na alteração de cor e na luminosidade do cimento dual convencional e fotoativado. As alterações do cimento autoadesivo não dependem da espessura da restauração.

\section{Acknowledgements}

The authors gratefully acknowledge the financial support from the São Paulo Research Foundation - FAPESP (Grant Process No. 2010/18813-0).

\section{References}

1. Radz GM. Minimum thickness anterior porcelain restorations. Dent Clin North Am 2011;55:353-370.

2. Alqahtani MQ, Aljurais RM, Alshaafi MM. The effects of different shades of resin luting cement on the color of ceramic veneers. Dent Mater J 2012;31:354-361.

3. Della-Bona A: Characterizing ceramics and the interfacial adhesion to resin: II- the relationship of surface treatment, bond strength, interfacial toughness and fractography. J Appl Oral Sci 2005;13:101109.

4. Pecho OE, Ghinea $\mathrm{R}$, Ionescu AM, Cardona JdeL, Paravina RD, Pérez MdelM. Color and translucency of zirconia ceramics, human dentine and bovine dentine. J Dent 2012;40:34-40.

5. Wang $F$, Takahashi $H$, Iwasaki N. Translucency of dental ceramics with different thicknesses. J Prosthet Dent 2013;110:14-20.

6. Stevenson B, Ibbetson R. The effect of the substructure on the colour of samples/restorations veneered with ceramic: a literature review. J Dent 2010;38:361-368.

7. Dozic A, Kleverlaan CJ, Meegdes M, Van der Zel J, Feilzer AJ. The influence of porcelain layer thickness on the final shade of ceramic 
restorations. J Prosthet Dent 2003;90: 563-570.

8. Lu H, Powers JM. Color stability of resin cements after accelerated aging. Am J Dent 2004;17:354-358.

9. Turgut $S$, Bagis B. Colour stability of laminate veneers: an in vitro study. J Dent 2011;39:57-64.

10. Myers ML, Caughman WF, Rueggeberg FA. Effect of restoration composition, shade, and thickness on the cure of a photoactivated resin cement. J Prosthodont 1994;3:149-157.

11. Hitz T, Stawarczyk B, Fischer J, Hämmerle CH, Sailer I. Are self-adhesive resin cements a valid alternative to conventional resin cements? A laboratory study of the long-term bond strength. Dent Mater 2012;28:1183-1190.

12. Archegas LR, Freire A, Vieira $S$, Caldas DB, Souza EM. Colour stability and opacity of resin cements and flowable composites for ceramic veneer luting after accelerated ageing. J Dent 2011;39:804-810.

13. Kilinc E, Antonson SA, Hardigan PC, Kesercioglu A. Resin cement color stability and its influence on the final shade of all-ceramics. J Dent 2011;39:30-36

14. CIE (Commision Internationale de I'Eclairage). Colorimetry technical report. CIE Pub. No 15, 2nd ed. Vienna, Austria: Bureau Central de La CIE, 1986, [corrected reprint 1986].

15. Devigus A, Lombardi G. Shading Vita In-ceram YZ substructures: influence on value and chroma, part II. Int J Comput Dent 2004;7:379388.

16. Devigus A, Lombardi G. Shading Vita YZ substructures: influence on value and chroma, part I. Int J Comput Dent 2004;7:293-301.

17. ASTM Standards G154-00a. Standard practice for operating fluorescent light apparatus for UV exposure of nonmettalic materials. v. 14.04. Annual Book of ASTM Standards, Pennsylvania; 2006:646-654.
18. Garcia LaF, Mundim FM, Pires-de-Souza FeC, Puppin Rontani RM, Consani S. Effect of artificial accelerated aging on the optical properties and monomeric conversion of composites used after expiration date. Gen Dent 2013;61:1-5.

19. Ghavam M, Amani-Tehran M, Saffarpour M. Effect of accelerated aging on the color and opacity of resin cements. Oper Dent 2010;35:605-609.

20. Schneider LF, Pfeifer CS, Consani S, Prahl SA, Ferracane JL. Influence of photoinitiator type on the rate of polymerization, degree of conversion, hardness and yellowing of dental resin composites. Dent Mater 2008;24:1169-1177.

21. Sideridou I, Achilias DS, Spyroudi C, Karabela M. Water sorption characteristics of light-cured dental resins and composites based on Bis-EMA/PCDMA. Biomaterials 2004;25:367-376.

22. Moharamzadeh $K$, Van Noort R, Brook IM, Scutt AM. HPLC analysis of components released from dental composites with different resin compositions using different extraction media. J Mater Sci Mater Med 2007;18:133-137.

23. Kucukesmen HC, Usumez A, Ozturk N, Eroglu E. Change of shade by light polymerization in a resin cement polymerized beneath a ceramic restoration. J Dent 2008;36:219-223.

24. Terzioslu H, Yilmaz B, Yurdukoru B. The effect of different shades of specific luting agents and IPS empress ceramic thickness on overall color. Int J Periodontics Restorative Dent 2009;29:499-505.

25. Cho BH, Lim YK, Lee YK. Comparison of the color of natural teeth measured by a colorimeter and Shade Vision System. Dent Mater 2007;23:1307-1312.
Received June 11, 2015 Accepted November 24, 2015 